\title{
Determining the Relationship Between Influence Tactics Used by School Principals and Leader- Member Exchange ${ }^{1}$
}

\author{
DOI: $10.26466 /$ opus.764564 \\ $*$ \\ Habib Özkan*- Yasin Avan** \\ * Prof Dr, Gaziantep Üniversity Faculty of Education Gaziantep / Turkey \\ E-Posta: ozgan@gantep.edu.tr \\ ORCID: $\underline{0000-0001-7496-058 \mathrm{X}}$ \\ ** Education inspector, MONE Sivas/Turkey \\ E-Posta: y.avan@hotmail.com \\ ORCID: $0000-0003-2622-2982$
}

\begin{abstract}
This study aimed to determine the relationship between influence tactics used by school principals and Leader-Member Exchange (LMX). It was designed with the correlational survey model. The research universe consisted of teachers working at public schools in the city center of Sivas/Turkey, the respondents involved 330 teachers from 30 randomly selected public schools and all the teachers were surveyed. SPSS 20.0 was used in the data analysis and as the data set showed normal distribution, means and standard deviation values were calculated. The Pearson product-moment correlation coefficient was estimated and Simple Linear Correlation Analysis was conducted. The research results indicated that influence tactics used by school principals to carry out a request have an impact on leadermember exchange and in particular, consultation tactic positively correlates with all the sub-dimensions of LMX to some extent. Thus, frequent use of tactics by the school principal may enhance leader-member exchange in school organizations. The research findings were discussed on the basis of similar studies and the paper concluded by offering several recommendations.
\end{abstract}

Key Words: Influence tactics, leadership, leader-member exchange, school principal.

\footnotetext{
${ }^{1}$ This article is the expanded version of an oral presentation submitted in $14^{\text {th }}$ International JTEFS/BBCC Conference on Sustainable Development, Culture, Education held in Konya/Turkey between $12^{\text {th }}$ and $14^{\text {th }}$ of May, 2016.
} 
ISSN:2528-9527

E-ISSN: 2528-9535

Yıl Year: 11

Cilt Volume: 17

Sayı Issue :38

Uluslararası Toplum Araştırmaları Dergisi

International Journal of Society Researches

Haziran June 2021

Makalenin Gelis Tarihi Received Date: 06/07/2020

Makalenin Kabul Tarihi Accepted Date: 27/05/2021

\title{
Okul Müdürlerinin Kullandıkları Etkileme Taktikleri ile Lider Üye Etkileşimi Arasındaki İlişkinin Belirlenmesi
}

*

\begin{abstract}
Bu araştırmanın amacı okul müdürlerinin kullandıklar etkileme taktikleri ile lider üye etkileşimi arasındaki ilişkinin belirlenmesidir. Çalışma ilişkisel tarama modeli ile desenlemiştir. Araştırmanın çalışma evrenini Sivas ili merkeze bağhl okullarda görev yapan öğretmenler oluşturmaktadır. Evrene ilişkin belirlenen örneklem Sivas ili merkezindeki random usulü ile seçilen 30 okul ve bu okullarda görev yapan öğretmenler oluşturmaktadır. 330 öğretmene ölçme aracı uygulanmıştır. Veri analizi SPSS paket programı ile yapılmış, normal dă̆̆lım gösterdiği tespit edilen veri setine parametrik testlerden ortalama, standart sapma ve değiş̧kenler arasındaki ilişkinin hesaplanmasında ve yorumlanmasında Pearson Momentler Çarpımı ve Basit Korelasyon tekniği uygulanmıştır. Araştırma sonuçları, okul müdürleri tarafindan bir istekte bulunmak için kullanılan etki taktiklerinin, lider üye değişimi üzerinde bir etkisinin olduğunu ve özellikle "istişarede bulunma etki taktiğinin" bir ölçüde lider üye etkileşimi'nin tüm alt boyutlarıyla pozitif ilişkili olduğunu göstermektedir. Bu yüzden okul müdürü tarafindan taktiğin sıklıkla kullanılması, okul örgütlerinde lider üye değişimini artırabilir. Elde edilen bulgulara göre ulaşılan sonuçlar benzer araştırma sonuçları ekseninde tartışılmış ve ulaşılan sonuçlar doğrultusunda çeşitli önerilere yer verilmiştir.
\end{abstract}

Anahtar Kelimeler: Etki taktiktikleri, liderlik, lider üye etkileşimi, okul müdürü 


\section{Introduction}

The societies established organizations to solve their problems, maintain their life, satisfy their needs and improve. These organizations have a big role in achieving the goals that societies want to gain. This role's realization depends on that they found their organizational structures in accordance to the needs of society and time. People who are considered to be one of the most important factors affecting the work of organizations can guide and direct of the goals of the organization only by understanding people's behavior. Organizational behavior which is known as the examination of human behaviors in an organization, analyses human behaviors in work environment and contemplate show the individual is affected by the organization, and thus exhibits behavioral changes (Özkalp and Kırel, 2013). The motivation and inclination of staff to work in a way that they can accomplish organizational goals depend on the condition that they adopt the goals and objectives of the organization. Staffs' motivation and tendency to work in a way that they can achieve organizational goals is conditional on adopting the goals and objectives of the organization. (Adler and Elmhorst, 1996; Gürgen, 1997; Güney, 2015).

\section{Influnce Tactics:}

The manager who have the responsibility to make the organization achieve its objectives by working with subordinates and through the use of their administrative skills and experience (Koçel, 2011) should have the ability to analytical thinking, decision making, communication, interpersonal relationships, flexibility and mastery in policies and procedures as well as technical, humane and conceptual knowledge to fulfill the management task well (Castro, Douglas, Hochwater, Ferris, Frink and Dwight, 2003; Chemers, 2000; Petersonand Van Fleet, 2004; Şimşek and Öğe, 2011). Managers must have the capacity of influencing subordinates to make them effective in achieving organizational goals. Influencing is the process of stirring individuals and it begins with the identification of the target person by the agent (Güney, 2016). The primary source of the initiation and maintenance of the influence process is the 
power of organizational leader (Başaran, 1992). Cable and Judge (2003) correlated the influence tactics used by managers with managerial personality and leadership styles. They are concluded that managers with high extroversion scores frequently used personal charm and selfappreciation tactics whereas managers with high life openness scores used negotiation less.

The best-known classification of influence tactics in the literature was created by Kipnis and his colleagues (1984). They (Kipnis, SwaffinSchmidt and Wilkinson, 1980) defined seven distinct influence tactics as the reason, friendliness, coalitions, bargaining and exchange, assertiveness, higher authority, and sanctions. Another classification created by Yukl and his colleagues (Yukl, Seifert and Chavez, 2008) and it is accepted as the basis of our research. They argued that 11 distinct influence tactics could be exploited in organizational communication process as follows:

- Rational Persuasion: Logical arguments and factual evidence are used by the agent to show that a request is feasible and relevant for important task objectives.

- Inspirational appeals: The target person's values and ideals are appealed to by the agent or the target person is encouraged to gain commitment for a request.

- Consultation: The target person's interests and recommendations are granted by a proposal.

- Ingratiation: The target person's being praised before or during an attempt to carry out a request by the agent.

- Exchange: The target person's being offered reciprocity in return for doing what the agent requests.

- Personal appeals: The target person's being asked to do a personal favor to carry out the agent's request.

- Coalition: The agent uses the support of others to influence the target to carry out a request.

- Legitimating: The legitimacy of a request is established by the agent thanks to the use of politics, regulations and institutional traditions.

- Pressure: The target person is exposed to threats, frequent checking, or persistent reminders to do something. 
- Collaboration: The target person's being offered to provide assistance or necessary resources to carry out a request by the agent.

- Apprising: The target person's being informed about personal and occupational benefits of carrying out a request.

\section{Leader-Member Exchange}

As a concept closely related to social relationships and group psychology, leadership is defined as the process of influencing group members to achieve organizational aims and objectives and up to now what is attracting for the human beings is the determination of leader characteristics (Hogg and Van Knippenberg, 2003; Northouse, 2001; Peterson and Hunt, 1997). In the 1970s, Leader Member Exchange (LMX) Theory focusing on the reciprocal relationships of hierarchical pairs was theorized (Bruins, 1999; Dulebohn, Bommer, Liden, Broucer and Ferris, 2011; Scandura, 1999; Chen, Lee, and Yeh, 2008). It is highlighted that leadership is not a possession of an individual only, and in this relationship, an individual in the guiding position should also be acknowledged by the target people (Baurer and Green, 1996; Eroğlu and İspir, 2006; Gerstner and Day, 1997).

William (1990) indicates that people assume several roles in line with the requirements of the job in the workplace. Therefore, there are various expectations of subordinates from superiors and vice versa (Dockery and Steiner, 1990; Scandura, 1999; William, 1990). The basic principle of leader-member exchange is leaders' developing relationships with followers in different qualities and the quality of these relationships will affect the attitudes and the behaviors of leader and the members (Ilies, Nahrgang and Morgeson, 2007). The relationship between leader and the members do not have to be homogeneous. Thus, some members may have more intimate and deeper relationships with their leaders and as a result it may provide them with some advantages such as earning trust and respect of a leader, having continual emotional support, obtaining formal and informal rewards and accessing detailed information (Norvapalo, 2014; Schriesheim, Castro and Cogliser, 1999; Xu Huang, Simon, Chan, Whing and Xinsheng, 2010; Yang, Yang and Lee, 2015). 


\section{The Relationship between Influence Tactics and Leader-Member Exchange}

A reasonable criterion for evaluating the effect of an agent's influence tactics is the quality of the relationship between leader and members. High quality interaction between leader and follower is an indicator of strong communication and mutual trust between the parties (Koçak and Çınar, 2020). An agent's influence tactics on subordinate may affect the quality of the future relationship, but it is a fact that the quality of the current relationship is determined by the tactical choice of the agent (Furst and Cable, 2008; Mc Farland et al., 2002; Yukl, et al., 2008). As the influence of the leader towards its members increases in the strength of the members hope, optimism, self-confidence and resistance against the difficulties can be expected (Yang et al., 2015). There are 11 downward influence tactics (persuasion with the mind, answering back, incentive demanding, obeying rules, informing, suppression, cooperation, appraisal, consultation, using personal closeness, creating a coalition with others). The characteristic of communication between leader and member is in positive relation to four main tactics and also informing, enforcing tactics in a study (Yukl and Michel, 2006).

Although the two are based on statistically valid and reliable frameworks, one of the instruments of this study, the target Influence Behavior Questionnaire (IBQ G) developed by (Yukl, et al., 2008) aims to test downward and horizontal influence tactics of the agent, and therefore sub-dimensions and area of use of the instrument are different from Kipnis and his colleagues (1980). The second instrument of the study is a multidimensional Leader-Member Exchange Scale (LMX-MDM-12) developed by Liden and Maslyn (1998) to determine the level of exchange between the agent and the targets in schools. It consists of 12 items and four dimensions as affect, loyalty, contribution and professional respect.

\section{The Purpose of Research}

The main objective of the study is to determine the most frequently used influence tactics by school principals according to teachers' opinions and find an answer to whether there is a relationship between the use of 
influence tactics and Leader-Member Exchange (LMX). Similar studies have done in different fields but there is no study in the field of education. Also, there is no study that determines the status of leader-member exchange on influencing tactics. Considering that this study will contribute to the relevant literature. Because of that the findings of this study is considered to be important. For this purpose, answers are searched to the following questions:

1. Which are the most frequently used influence tactics of school principals according to teachers' opinions?

2. What is the relationship between influence tactics used by school principals and Leader-Member Exchange (LMX)?

\section{Method}

\section{Research Design}

This study was designed with the correlational survey model. Survey research usually done larger samples is used to determine participants' views on a topic/event or characteristics such as interests, skills, abilities and attitudes etc. are depicted (Büyüköztürk, Çakmak, Akgün, Karadeniz and Demirel, 2013). This method also necessitates describing the events, individuals or objects on their own terms and as they are. No effort is welcomed to change or affect the present circumstances.

\section{Participants of the Study}

The research universe consisted of teachers working at public schools in the city center of Sivas/Turkey. The respondents of the study involved the teachers from 30 randomly selected public schools and 345 teachers were surveyed, however 15 surveys were omitted due to inconvenience. Therefore, statistical analyses were made on 330 surveys. The distribution of the participants in terms of gender, age, professional seniority, educational stage, educational background and teaching field are as follows: 
Table 1. Participant Profile of the Study

\begin{tabular}{|c|c|c|c|}
\hline & & $\mathrm{f}$ & $\%$ \\
\hline \multirow[t]{5}{*}{ Gender } & Female & 175 & 53,0 \\
\hline & Male & 155 & 47,0 \\
\hline & Total & 330 & 100 \\
\hline & 30 and under & 116 & 35,2 \\
\hline & Between 31-40 & 157 & 47,6 \\
\hline \multirow[t]{2}{*}{ Age } & 41 and older & 57 & 17,3 \\
\hline & Total & 330 & 100 \\
\hline \multirow[t]{5}{*}{ Professional seniority } & $1-10$ years & 182 & 55,2 \\
\hline & $11-20$ years & 102 & 30,9 \\
\hline & 21 and more & 46 & 13,9 \\
\hline & Total & 330 & 100 \\
\hline & Primary School & 62 & 18,8 \\
\hline \multirow[t]{4}{*}{ Educational stage } & Secondary School & 147 & 44,5 \\
\hline & High School & 121 & 36,7 \\
\hline & Total & 330 & 100 \\
\hline & $\begin{array}{l}\text { B.A. in Faculty of } \\
\text { Education }\end{array}$ & 219 & 66,4 \\
\hline \multirow[t]{4}{*}{$\begin{array}{l}\text { Educational } \\
\text { background }\end{array}$} & $\begin{array}{l}\text { B. A. in Faculty of Arts \& } \\
\text { Sciences }\end{array}$ & 69 & 20,9 \\
\hline & Master of Arts & 42 & 12,7 \\
\hline & Total & 330 & 100 \\
\hline & Social Sciences & 176 & 53,3 \\
\hline \multirow[t]{4}{*}{ Teaching field } & Natural Sciences & 99 & 30 \\
\hline & Primary School Education & 32 & 9,7 \\
\hline & Vocational Education & 23 & 7,0 \\
\hline & Total & 330 & 100 \\
\hline
\end{tabular}

As shown in Table 1. the $47 \%$ of respondents is men and $53 \%$ of women. The teachers 30 and below consists of $35,2 \%$ of the respondents, while their $47 \%$ are between $31-40$ and $17,3 \%$ are 41 and higher. According to the distribution of participants in terms of professional seniority, the largest proportion of the participants belongs to $1-10$ years with $55,2 \%$ and it is followed by 11-20 years with $30,9 \%$ and 21 and upper with $13,9 \%$ respectively. Whereas the ratio of the respondents working in primary school is $18,8 \%$, teachers in secondary school is $44,5 \%$ and teachers in high school is $36,7 \%$. The $66,4 \%$ of the respondents graduated from B. A. in Faculty of Education, 20,9\% of teachers from B. A. in Faculty of Arts \& Sciences and only 12,7\% of teachers from Master of Arts. Teaching fields of the participants vary as Social Sciences with 53,3\%, Natural Sciences 
with 30\%, Primary School Education with 9,7\%, and Vocational Education with $7 \%$.

\section{Data Collection and Instruments}

Three different instruments were used in the study. The first instrument was the target Influence Behavior Questionnaire (IBQ G) developed by (Yukl, et al., 2008) to determine the influence tactics used by school principals on teachers. It was translated into Turkish by Gözü (2012). In this research, the translated version of the scale was checked, back translations were done and revised again by linguistics experts. Therefore, it was decided that there was no need to retranslate the original scale and the translated version of the 44-item scale by Gözü (2012) was used by permission. The second instrument used is a multidimensional LeaderMember Exchange Scale (LMX-MDM-12) developed by Liden \& Maslyn (1998) to determine the level of exchange between the agent and the targets. It consists of 12 items and four dimensions as affect, loyalty, contribution and professional respect. The last instrument developed by the researcher to determine the demographic characteristics of the respondents. The instruments of the study about influence tactics and leader-member exchange were equal interval scales and the research data were normally distributed (Kolmogorov-Smirnov p-value for influence tactics was $.020>0.05$ and leader-member exchange was $080>0.05$ ). Therefore, the interpretation of the skewness and kurtosis coefficients were considered unnecessary. The internal consistency of the scales was tested by calculating the Cronbach's Alpha reliability coefficient. The Cronbach's alpha reliability coefficient for influence tactics was 0.936 and leader-member exchange was 0.922 indicating that both scales had high levels of reliability. The research data were analyzed after testing the reliability and structural validity. 


\section{Findings}

\section{A- Tactics Used by School Principals to Influence Teachers}

Table 2. Tactics Used by School Principals to Influence Teachers

\begin{tabular}{cclc}
\hline Ranking & Influence Tactics & $\overline{\mathrm{X}}$ & ss \\
\hline 1 & Legitimating & 15,47 \\
2 & & 3,56 \\
& & 15,37 \\
3 & Rational Persuasion & 3,55 \\
& & 15,23 \\
4 & Pressure & 3,27 \\
& & 14,62 \\
5 & Inspirational appeals & 3,60 \\
& & 14,52 \\
6 & Collaboration & 3,86 \\
& & 13,93 \\
7 & Apprising & 4,16 \\
& & 13,88 \\
8 & Consultation & 3,80 \\
& & 12,84 \\
9 & Ingratiation & 4,63 \\
& & 10,12 \\
10 & Exchange & 4,94 & \\
11 & Coalition & 8,82 & 4,16 \\
\hline
\end{tabular}

In Table 2, it was clear that school principals most frequently used legitimating tactic $(\bar{X}=15,47)$ to influence teachers and it was followed by rational persuasion tactic $(\bar{X}=15,37)$. On the other hand, personal appeals tactic was the last tactic used by school principals. It could be asserted that school principals did not use personal appeals too much in order to protect the social distance with the subordinates due to their superior status legally. In addition, school principals exploited pressure tactic $(\overline{\mathrm{X}}$ $=15,23)$ and inspirational appeals tactic $(\overline{\mathrm{X}}=14,62)$ at a relatively high level. These types of tactical use may also be associated with the power bases of school principals. To illustrate, it can be suggested that they used their legitimate power with legitimating tactic, expert power with rational persuasion tactic, coercive power with pressure tactic, and reward power with inspirational appeals tactic. 


\section{B-The Relationship between Influence Tactics of School Principals and Leader-Member Exchange}

Pearson product-moment correlation coefficient was used in order to determine the relationship between the sub-dimensions of influence tactics used by school principals and Leader-Member Exchange (LMX) sub-dimensions. The obtaine data were evaluated considering the following intervals (Kalayc1, 2010).

Figure 1. Values for the Correlation Coefficient and Correlation between Variables

\begin{tabular}{lc}
\hline Values for the correlation coefficient & Correlation between variables \\
\hline $0,00-0,25$ & Very small \\
$0,26-0,49$ & Small \\
$0,50-0,69$ & Modest \\
$0,70-0,89$ & Large \\
$0,90-1,00$ & Very large \\
\hline
\end{tabular}

Table 3. The Relationship between Legitimating Tactic and the Sub-Dimensions of Leader-Member Exchange

\begin{tabular}{llcccc}
\hline & & Affect & Loyalty & Contribution & Respect \\
\hline Legitimating & Pearson Correlation &, $366^{* *}$ &, $285^{* *}$ &, $326^{* *}$ &, $401^{* *}$ \\
& Sig. (2-tailed) &, 000 &, 000 &, 000 &, 000 \\
& $\eta^{2}$ &, 13 & 0,081 & 0,10 & 0,16 \\
\hline
\end{tabular}

${ }^{* *} p<.01$

It was clear that there were small positive correlations between legitimating tactic and the sub-dimension of affect $(\mathrm{r}=.366, \mathrm{p}<.01)$, the subdimension of loyalty $(\mathrm{r}=.285, \mathrm{p}<.01)$, the sub-dimension of contribution $(\mathrm{r}=$ $.326, \mathrm{p}<.01)$ and the sub-dimension of professional respect $(\mathrm{r}=.401, \mathrm{p}<.01)$.

Table 4. The relationship between Rational Persuasion Tactic and the Sub-dimensions of Leader-Member Exchange

\begin{tabular}{|c|c|c|c|c|c|}
\hline & & Affect & Loyalty & Contribution & Pespect \\
\hline \multirow{3}{*}{ 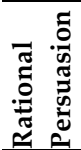 } & Pearson Correlation & ,534* & $430^{* *}$ & $499^{* *}$ & $620^{4}$ \\
\hline & Sig. (2-tailed) & ,000 & ,000 & ,000 & , 000 \\
\hline & $\eta^{2}$ & 0,29 & 0,19 & 0,25 & 0,38 \\
\hline
\end{tabular}

${ }^{* *} p<.01$ 
According to the table, there was a modest positive correlation between rational persuasion tactic and the sub-dimension of contribution $(\mathrm{r}=.499, \mathrm{p}<.01)$. In addition, there was a modest positive correlation between rational persuasion tactic and the sub-dimension of professional respect $(\mathrm{r}=.620, \mathrm{p}<.01)$. The eta squared value indicated that $38 \%$ of professional respect of LMX was explained by rational persuasion tactic, and the rest may be explained by other influence tactics.

Table 5. The relationship between Pressure Tactic and the Sub-dimensions of LeaderMember Exchange

\begin{tabular}{llcccc}
\hline & Affect & Loyalty & Contribution & Respect \\
\hline & Pearson Correlation &, $266^{* *}$ &, 094 &, $146^{* *}$ &, $289^{* *}$ \\
Sig. (2-tailed) &, 000 &, 088 &, 008 &, 000 \\
& $\eta^{2}$ & 0,07 & 0,009 & 0,021 & 0,0838 \\
\hline \multirow{0}{0}{} & & & &
\end{tabular}

Data analysis demonstrated that there was a very small positive correlation between pressure tactic and the sub-dimension of loyalty $(\mathrm{r}=$ $.094, \mathrm{p}>.01)$. This finding suggested that pressure tactic had almost no impact on the loyalty dimension of LMX.

Tablo 6. The relationship between Inspirational Appeals Tactic and the Subdimensions of Leader-Member Exchange

\begin{tabular}{|c|c|c|c|c|c|}
\hline & & Affect & Loyalty & Contribution & Respect \\
\hline \multirow{3}{*}{ 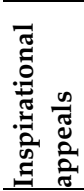 } & $\begin{array}{l}\text { Pearson } \\
\text { Correlation }\end{array}$ & $494^{* *}$ & $437^{* *}$ & $474^{* *}$ &, $500^{* *}$ \\
\hline & Sig. (2-tailed) & ,000 & ,000 & ,000 & ,000 \\
\hline & $\eta^{2}$ & 0,244 & 0,191 & 0,225 & 0,250 \\
\hline
\end{tabular}

It was found that there were modest positive correlations between inspirational appeals tactic and the sub-dimension of affect $(\mathrm{r}=.494, \mathrm{p}<.01)$, the sub-dimension of loyalty $(\mathrm{r}=.437, \mathrm{p}<.01)$, the sub-dimension of contribution $(\mathrm{r}=.474, \mathrm{p}<.01)$ and the sub-dimension of professional respect $(\mathrm{r}=.500, \mathrm{p}<.01)$. 
Determining the Relationship Between Influence Tactics Used by School Principals and LeaderMember Exchange

Table 7. The relationship between Collaboration Tactic and the Sub-dimensions of Leader-Member Exchange

\begin{tabular}{|c|c|c|c|c|c|}
\hline & & Affect & Loyalty & Contribution & Respect \\
\hline \multirow{3}{*}{ 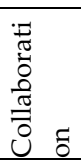 } & Pearson Correlation &, $544^{* *}$ &, $516^{* *}$ &, $534^{* *}$ &, $543^{* *}$ \\
\hline & Sig. (2-tailed) & ,000 & ,000 & ,000 & ,000 \\
\hline & $\eta^{2}$ & 0,267 & 0,285 & 0,285 & 0,295 \\
\hline
\end{tabular}

It was clear that there was a modest positive correlation between collaboration tactic and the sub-dimension of affect $(\mathrm{r}=.544, \mathrm{p}<.01)$. The eta squared value indicated that nearly $27 \%$ of the affectsub-dimension of LMX was explained by collaboration tactic, and the rest may be explained by other influence tactics. There were modest positive correlations between collaboration tactic and the sub-dimension of loyalty $(r=.516$, $\mathrm{p}<.01)$ and the sub-dimension of contribution $(\mathrm{r}=.534, \mathrm{p}<.01)$. The correlation between collaboration tactic and the sub-dimension of professional respect $(\mathrm{r}=.543, \mathrm{p}<.01)$ was also modestly positive. The eta squared value indicated that nearly $30 \%$ of the professional respect subdimension of LMX was explained by collaboration tactic, and the rest may be explained by other influence tactics.

Table 8. The relationship between Apprising Tactic and the Sub-dimensions of Leader Member Exchange

\begin{tabular}{|c|c|c|c|c|c|}
\hline \multirow{4}{*}{ 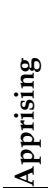 } & & Affect & Loyalty & Contribution & Respect \\
\hline & Pearson Correlation &, $499^{* *}$ & $416^{* *}$ & $429^{* *}$ & $470^{* *}$ \\
\hline & Sig. (2-tailed) & ,000 & ,000 & ,000 & ,000 \\
\hline & $\eta^{2}$ & 0,173 & 0,173 & 0,184 & 0,221 \\
\hline
\end{tabular}

According to the table, there was a modest positive correlation between apprising tactic and the sub-dimension of affect $(\mathrm{r}=.499, \mathrm{p}<.01)$. There was also a modest positive correlation between apprising tactic and the sub-dimension of professional respect $(\mathrm{r}=.470, \mathrm{p}<.01)$.

Data analysis demonstrated that there was a modest positive correlation between consultation tactic and the sub-dimension of affect $(\mathrm{r}=$ $.560, \mathrm{p}<.01)$. 
Table 9 The relationship between Consultation Tactic and the Sub-dimensions of Leader-Member Exchange.

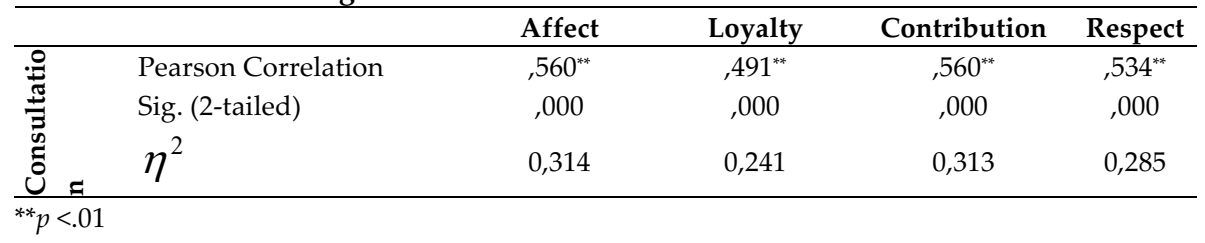

The eta squared value indicated that nearly $31 \%$ of the affect subdimension of LMX was explained by consultation tactic, and the rest $69 \%$ may be explained by other influence tactics. There were modest positive correlations between consultation tactic and the sub-dimension of loyalty $(\mathrm{r}=.491, \mathrm{p}<.01)$ and the sub-dimension of professional respect $(\mathrm{r}=.534$, $\mathrm{p}<.01)$. The correlation between consultation tactic and the sub-dimension of contribution $(\mathrm{r}=.560, \mathrm{p}<.01)$ was also modestly positive. The eta squared value indicated that nearly $31 \%$ of the contribution sub-dimension of LMX was explained by consultation tactic, and the rest may be explained by other influence tactics.

Table 10. The Relationship between Ingratiation Tactic and the Sub-dimensions of Leader-Member Exchange

\begin{tabular}{|c|c|c|c|c|c|}
\hline & & Affect & Loyalty & Contribution & Respect \\
\hline \multirow{4}{*}{ مَّ } & Pearson & $456^{* *}$ & $491^{* *}$ &, $508^{* *}$ & $372^{* *}$ \\
\hline & Correlation & & & & \\
\hline & $\begin{array}{l}\text { Sig. } \\
\text { tailed })\end{array}$ & ,000 & ,000 & ,000 & ,000 \\
\hline & $\eta^{2}$ & 0,208 & 0,241 & 0,258 & 0,139 \\
\hline
\end{tabular}

It was found that there were modest positive correlations between ingratiation tactic and the sub-dimension of loyalty $(\mathrm{r}=.491, \mathrm{p}<.01)$ and the sub-dimension of contribution $(\mathrm{r}=.508, \mathrm{p}<.01)$. 
Determining the Relationship Between Influence Tactics Used by School Principals and LeaderMember Exchange

Table 11. The relationship between Exchange Tactic and the Sub-dimensions of Leader-Member Exchange

\begin{tabular}{|c|c|c|c|c|c|}
\hline & & Affect & Loyalty & Contribution & Respect \\
\hline \multirow{3}{*}{ 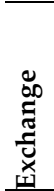 } & $\begin{array}{l}\text { Pearson } \\
\text { Correlation }\end{array}$ & $159^{* *}$ & $223^{* *}$ & $285^{* *}$ & $128^{*}$ \\
\hline & Sig. (2-tailed) & ,004 & , 000 & , 000 & 021 \\
\hline & $\eta^{2}$ & 0,025 & 0,050 & 0,081 & 0,016 \\
\hline
\end{tabular}

According to the table, there were very small positive correlations between exchange tactic and the sub-dimension of affect $(\mathrm{r}=.159, \mathrm{p}<.01)$, the sub-dimension of loyalty $(\mathrm{r}=.223, \mathrm{p}<.01)$ and the sub-dimension of professional respect $(\mathrm{r}=.128, \mathrm{p}<.01)$.

Table 12. The relationship between Coalition Tactic and the Sub-dimensions of Leader-Member Exchange.

\begin{tabular}{llccc}
\hline & Affect & Loyalty & Contribution & Respect \\
\hline Pearson Correlation &, 055 &, $171^{* *}$ &, $165^{* *}$ &,- 036 \\
Sig. (2-tailed) &, 324 &, 002 &, 003 &, 515 \\
$\overbrace{0}^{* *} \eta^{2} p<.01$. & 0,003 & 0,029 & 0,027 & 0,001 \\
\hline & & & &
\end{tabular}

It was clear that though there was a very small positive correlation between coalition tactic and the sub-dimension of affect $(\mathrm{r}=.055, \mathrm{p}<.01)$, it was statistically non-significant. In addition, there was a very small negative correlation between coalition tactic and the sub-dimension of professional respect $(\mathrm{r}=-.036, \mathrm{p}<.01)$ though it was statistically nonsignificant.

Though there was a very small positive correlation between personal appeals tactic and the sub-dimension of affect $(r=.063, p<.01)$, it was statistically non-significant. 
Table 13.The relationship between Personal Appeals Tactic and the Sub-dimensions of Leader-Member Exchange

\begin{tabular}{|c|c|c|c|c|c|}
\hline & & Affect & Loyalty & Contribution & Respect \\
\hline \multirow{3}{*}{ 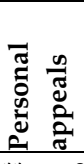 } & Pearson Correlation & 063 & $175^{* *}$ & $268^{* *}$ &,- 010 \\
\hline & Sig. (2-tailed) & ,256 & 001 & ,000 & ,858 \\
\hline & $\eta^{2}$ & 0,004 & 0,031 & 0,072 & -.010 \\
\hline
\end{tabular}

In addition, there was a very small negative correlation between personal appeals tactic and the sub-dimension of professional respect $(\mathrm{r}=$ $-.010, \mathrm{p}<.01)$ though it was statistically non-significant.

\section{Discussion, Conclusion}

The main aim of the current study was to determine the relationship between influence tactics used by school principals and Leader-Member Exchange (LMX). Yukl et al., (2008) pointed out that a reliable and suitable criterion to evaluate the effects of the agent's influence tactics is the characteristics of the leader-memberex change and some of the influence tactics may lead to mutual causalities with LMX. According to research results, legitimating was the most frequently used influence tactic by school principals on teachers. In researches conducted by Gözü (2012), Tekben and Koşar, (2019) the tactic used most by school principals to influence teachers revealing that it is" compliance with rules " influencing tactic creates consistency the study finding. According to this result, school principals benefit from harsh influence tactics while influencing teachers. It could be claimed that school principals intended to protect the social distance with their subordinates due to their superior status legally.It could be claimed that school principals intended to protect the social distance with their subordinates due to their superior status legally

It was clear that school principals use rational persuasion secondly and personal closeness at least. These used tactics can be associated with power sources possessed by school principals. It can be commented that the tactic of obeying the rules use their legal power, the tactic of rational persuasion uses their technical power, the tactic of suppression use their punitive power, the tactic of incentive demanding use their reward power 
(Bruins, 1999). It was remarkable that there were modest positive correlations between rational persuasion tactic and the sub-dimensions of contribution and professional respect. Thus, the success of schools as open systems is highly associated with the school principal's effective use of rational persuasion tactic to increase the loyalty of members to the organization and to build respect between teachers and the principal (Güney, 2016 ; İnce and Gül, 2005 ).

Another prominent research finding was that there were modest positive correlations between inspirational appeals tactic and the subdimensions of affect, contribution, and professional respect. Raile (2008) indicates that inspirational appeals tactic contributes much to the identification of subordinates through the feelings of perceived autonomy and belongingness. Affect, loyalty, contribution and professional respect were identified by Liden and Maslyn (1998) as the sub-dimensions of leader-member exchange. The sub-dimension of affect focuses much on the connection based on interpersonal relationships. Some of the indicators of this sub-dimension are the subordinate's appreciation about the leader independent of the agent's business identity and desire for the friendship of leaders. Özdemir and Arslan (2015) extrapolated that the use of inspirational appeals tactic had positive outcomes such as motivation, self-determination and convincing the teachers on achieving objectives. It is clear that the teachers who have faith in organizational goals thanks to the inspirational appeals tactic are encouraged to work hard by the school principals with the professional respect sub-dimension of LMX (Özgan and Avan, 2016).

According to the research results, there were modest positive correlations between apprising tactic and the sub-dimensions of affect and professional respect. Yukl et al. (2008) defined apprising tactic as the agent's being informed about personal and occupational benefits of carrying out a request. It is supposed that the professional respect of school principals would increase in teachers' eye who are informed about personal and occupational benefits of carrying out a request and subordinates may develop feelings toward the leaders such as appreciation of school principal independent of the agent's school identity and desire for the friendship of school principal. A school principal should develop a transparent egalitarian understanding among members in 
workload distribution and reward sharing. In the process of sharing resources, should be developed a leader-member relationship, individual and group level information procedures should be implemented (Shammariand and Ebrahim, 2015).

The research results indicated that there were modest positive correlations between consultation tactic and the sub-dimensions of affect, contribution, loyalty and professional respect. In their research on the consequences of using influence tactics on subordinates, Yukl et al., (2006) concluded that rational persuasion, inspirational appeals, collaboration, and consultation are the influence tactics that most likely to result in subordinates' commitment. Therefore, they were identified as core tactics. Similar results to this research finding were also revealed by Katlav and Perçin (2019), Fettahlıoğlu and Akdoğan (2019), Tekben and Koşar (2019). Tekben and Koşar (2019), stated that school principals should use more moderate tactics (appreciation, informing, cooperation, consultation, persuasion through reason) while influencing teachers. Fettahlığlu \& Akdoğan (2019), revealed that there is a high level of positive directional meaningful relationship between the emotion sub-dimension of leading member interaction and the manager-trust sub-dimension of organizational trust.

Another research finding was that there were modest positive correlations between ingratiation tactic and the sub-dimensions of contribution and loyalty. According to Katlav and Perçin (2019), there is a relationship between influence tactics and job performance (task and contextual). When this tactic is used for teachers, increases the benefits and performance they provide to each other with the relationship between the leader and the member through contribution dimension, which is the lower dimension of the leader member interaction

An important research finding was that there were very small or small positive correlations between pressure tactic and the subdimensions of affect, contribution, and professional respect. The examination of all the research results together demonstrates that the most frequently used influence tactics by school principals on teachers are legitimating, rational persuasion and pressure respectively whereas personal appeals is the least exploited tactic. It was extrapolated that there were small positive correlations between legitimating tactic and the sub- 
dimensions of affect, contribution, loyalty and professional respect (Katrinli, Atabay, Günay and Güneri, 2008). There will be no quality leader-subordinate relationship if the interaction of school principal and teachers is only based on formal rules (Brower, Schoorman and Tan, 2000).

It was concluded that there were modest positive correlations between rational persuasion tactic and the sub-dimensions of contribution and professional respect. The use of rational persuasion improves the school principals' professional respect in teachers' eyes through encouraging school principal and teachers to work together and providing help. It can be claimed that the frequent and effective use may be useful.

There is a meaningful relationship positively poor or too poor between affect, contribution and professional respect dimensions with the tactic of suppression. In the case of the principal's usage to this tactic, the leader-member interaction will not be about expected degree. Therefore, it is clear that the frequent exploitation by the school principal will not result in positive leader-member exchange.

The research results indicated that influence tactics used by school principals to carry out a request have an impacton leader-member exchange and in particular, consultation tactic positively correlates with all the sub-dimensions of LMX to some extent. Thus, the frequent exploitation by the school principal may enhance leader-member exchange in school organizations. It can be suggested that the use of proper tactics is closely related to organizational functioning. Therefore, the school principals' use of influence tactics affecting leader-member exchange positively will also yield organizational and individual benefits. Some recommendations were given by considering the importance of influence tactics and leader-member exchange in achieving organizational goals and creating a positive organizational climate.

- In the context of increasing to corporate communication, seminars and in-service training about influence tactics and leader-member interaction can be provided to managers and teachers:

- In the context of increasing to corporate communication, seminars and in-service training about influence tactics and leader-member interaction can be provided to managers and teachers 
- As there is a very limited number of research on leader-member exchange in school organizations, similar research may be conducted in association with the variables such as leadership theories, organizational commitment, organizational justice, organizational climate and power bases.

- The results obtained in a quantitative research can be enriched by means of qualitative interviews to have a deeper understanding of the relationship between leader-member exchange and influence tactics.

- In schools, experimental studies should be conducted in accordance with the characteristics of the participants to determine the appropriate strategies specific to the school conditions and to determine the relevance of leader-memberex change with appropriate tactics.

- The data of current study were obtained from only one geographical destination. To reach more descriptive and more generalizable results, it is advisable to conduct research with a wider number of participants in different geographical regions or provinces.

\section{References}

Adler, R. B.,and Elmhorst, J. M.(1996). Communicating at Work (5th ed). New York: McGraw-Hill.

Başaran, İ. E. (1992). Yönetimde insan ilişkileri. Ankara: Kadığlu.

Baurer, T. N., and Green, G. S. (1996). Development of leader-member exchange Longitudinal test. The Academy of Management Journal, 36(6), 1538-1567.

Bruins, J. (1999). Social power and influence tactics: A theoretical introduction. Journal of Social Issues, 55, 7-14.

Brower, H.H., Schoorman, F.D., and Tan, H.H. (2000). A Model of Relational Leadership: The Integration of Trust and Leader-Member Exchange, Leadership Quarterly, 11(2), 227-250.

Büyüköztürk, Ş. Çakmak, E. K., Akgün, Ö. E., Karadeniz, Ş., and Demirel, F. (2013). Bilimsel araştırma yöntemleri.Ankara: Pegem Akademi. 
Castro, S. L., Douglas, C., Hochwarter, W. A., Ferris, G. R., and Frink, D. D. (2003). The effects-of positive affect and gender on the influence tactics-job performance relationship. Journal of Leadership $\mathcal{E}$ Organizational Studies, 10(1), 1-18

Cable, D. M. and Judge, T. A. (2003). Managers' upward influence tactic strategies: The role of manager personality and supervisor leadership style. Journal of Organizational Behavior, 24, 197-214.

Chemers, M. M. (2000). Leadership research and theory: A functional integration. Group Dynamics: Theory, Research, and Practice, 4, 27-43

Chen, C. H., Lee, H. M., and Yeh, Y. (2008). The antecedent and consequence of person-organization fit: Ingratiation, similarity, hiring recommendations and job offer. International Journal of Selection and Assessment, 16, 210-219.

Dockery, T. M., and Steiner, D. D. (1990). The role of the initial interaction in leader-member exchange. Group E Organization Management, 15(4), 395413

Dulebohn, J., Bommer, W., Liden, R., Broucer, R., and Ferris, G. (2011). A meta-analysis of antecedents and consequences of leader-member exchange: Integrating the past with an eye toward the future. Journal of Management, 38(6), 1715-1759

Eroğlu, E. and İspir, N. B. (2006). Örgütsel iletişim sürecinde yönetimsel ikna ve etkileme örnek olay incelemesi. 2nd National Public Relations Symposium, Turkey (64-70).

Fettahlıŏglu, Ö.O. and Akdoğan, Z. (2019). Lider üye etkileşiminin örgütsel güven algısı üzerine etkileri. International Journal of Disciplines Economics $\mathcal{E}$ Administrative Sciences Studies, 5(13), 295-310

Furst, S. A., and Cable, D. M. (2008). Employee resistance to organizational change: Managerial influence tactics and leader-member exchange. Journal of Applied Psychology, 93(2), 453.

Gerstner, C. R., and Day, D. V. (1997). Meta-analytic review of leader-member exchange theory: Correlates and construct issues. Journal of Applied Psychology, 82, 827-844.

Gözü, C. (2012). Influence tactics and leadership effectiveness in Turkey and the USA: Mediatıng role of subordinate commitment. Doctoral Dissertation, University at Albany, New York.

Güney, S. (2015). Liderlik. Ankara:Nobel. 
Güney, G. (2016). Etkileme taktiklerinin astın örgüte bağhlı̆̆ına etkisinde lidere bağhlı̆̆ın ve güvenin rolü. Yüksek Lisans Tezi. Kara Harp Okulu Savunma Bilimleri Enstitüsü, Ankara.

Gürgen, H. (1997). Örgütlerde iletişim kalitesi. İstanbul: Der.

Hogg, M. and Van Knippenberg, D. (2003). Social identity and leadership processes in group. Advances in Experimental Social Psychology, 35(1), 1-52.

Ilies R., Nahrgang JD. and Morgeson, F.P. (2007). Leader-member exchange and citizenship behaviors: A meta-analysis. Journal of Applied Psychology, 92(2), 269-277.

İnce, M., and Gül, H. (2005). Yönetimde yeni bir paradigma: Örgütsel bă̆lılık. Ankara: İleri Giden Ofset,.

Kalayc1, Ş. (2010). Faktör analizi, SPSS uygulamalı çok değişkenli istatistik teknikleri. Ankara: Asil Yayınları.

Katrinli, A., Günay, G., and Guneri, B. (2008). Leader-member exchange, organizational identification and the mediating role of job involvement for nurses. Journal of Advanced Nursing, 64(4), 354-362

Katlav, E, Ö., and Perçin, N, Ş.(2019). Algılanan etkileme taktiklerinin iş performansı üzerindeki etkisini belirlemede kontrol odağının düzenleyici rolü: otel işletmelerinde bir uygulama . Sosyal Bilimler Araştırmaları Dergisi, EkonomiESiyaset Özel Sayısı, 225-244

Kipnis, D. Schmidt, S. M., and Wilkinson, I. (1980). Intraorganizational Influence Tactics: Explorations in getting one's way. Journal of Applied Psychology, 65(4), 440-452.

Kipnis, D., Schmidt, S. M., Swaffin-Smith, C., and Wilkinson, I. (1984). Patterns of managerial influence: Shotgun managers, tacticians, and bystanders. Organizational Dynamics, 12(3), 58-67.

Koçak, D. Çınar, O. (2020). Lider-üye etkileşimi ve örgütsel sessizlik arasındaki ilişkide pozitif psikolojik sermayenin aracı rolü: Hizmet sektöründe bir araştırma. Atatürk Üniversitesi Sosyal Bilimler Enstitüsü Dergisi, 24(1), 1-20

Koçel, T. (2011). İşletme yöneticiliği. İstanbul: Beta Yayıncılık.

Liden, R. C., and Maslyn, J. M. (1998). Multidimensionality of leader-member exchange: An empirical assessment through scale development. Journal of Management, 24(1), 43-72. 
McFarland, L. A., Ryan, A. M., and Kriska, S. D. (2002). Field study investigation of applicant use of influence tactics in a selection interview. The Journal of Psychology: Interdisciplinary and Applied, 136(4), 383-398

Northouse, P.G. (2001). Leadership. Thousand Oaks. California CA: Sage Publications.

Norvapalo, K. (2014). The quality and development of the leader-follower relationship and psychological capital: a longitudinal case study in a higher education context. Jyväskylä Studies in Business and Economics, (144), University of Jyväskylä Publications.

Ozgan, H. andAvan, Y. (2016). Examination of the relationship between influence tactics used by school principals and leader-member exchange (The Sample of Sivas Province). 14 th International JTEFS/BBCC Conference on Sustainable Development, Culture, Education, Konya,Turkey.

Özdemir, M., and Arslan, M.C. (2015). Okul müdürlerinin kullandıkları etki taktiklerinin öğretmenler üzerindeki etkileri (Gaziantep Case Study). 6th International Conference on New Horizons in Education, 60-61. Barselona, İspanya.

Özkalp, E., and Kırel, Ç. (2013). Örgütsel davranış. Bursa: Ekin.

Pehlivan, Ü. (2018). İlköğretim kurumu yöneticilerinin kullandikları etkileme taktikleri ile öğretmenlerin örgütsel bağhllı̆̆ı arasındaki ilişki. Yüksek Lisans Tezi, Gazi Üniversitesi, Ankara.

Peterson, T. O. and Van Fleet, D. D. (2004). The ongoing legacy of r.l. katz. an updated typology of management skills. Management Decision, 42(10), 1297-1308.

Peterson,M.F. and Hunt, J.G.(1997). International perspectives on international leadership. Leadership Quarterly, 8(3), 203-231.

Raile, A.N.W. (2008). Managerial downward influence tactics: Considering the "wy" of employee commitment. Doctoral Dissertation, Michigan State University

Remus, I., NahrganG, J., and Morgeson, F, (2007). leader-member exchange and citizenship behaviors: A meta-analysis. Journal of Applied Psychology, 92(2), 269-277.

Shammari, A. M., and Ebrahim. E, H. (2015). Leader-member exchange and organizational justice in bahraini workgroups. Management and Organizational Studies, 2(1), 87-94. 
Scandura, T. A. (1999). Rethinking leader- member exchange: An organizational justice perspective. The Leadership Quarterly, 10(1),25-40.

Schriesheim, C. A., Castro, S. L., and Cogliser, C. C. (1999). Leader-member exchange (LMX) research: A comprehensive review of theory, measurement, and data-analytic practices. Leadership Quarterly, 10(1), 63113

Şimşek, Ş., and Öğe, S. (2011). Insan kaynakları yönetimi. Konya: Eğitim Kitapevi.

Tekben, İ and Koşar, D. (2019). Ortaöğretim kurumlarında görev yapan müdürlerin kullandıkları etkileme taktikleri ile öğretmenlerin örgütsel bağlllıkları arasındaki ilişkinin incelenmesi. İnönü Üniversitesi Eğitim Fakültesi Dergisi, 20(3), 987-1007.

William, A. K. (1990). Psychological conditions of personal engagement and disengagement at work. Academy of Management Journal, 33(4), 692-724.

Xu Huang, Simon C. H. Chan, Wing Lam and Xinsheng Nan, (2010). The joint effect of leader-member exchange and emotional intelligence on burnout work performance in call centers in China.The International Journal of Human Resource Management, 21(7), 1124-1144.

Yang, H. C., Yang, W. R., and Lee, C. H. (2015). Influence of organizational exchange relationship on motivation: Mediating effect of positive psychological capital and self-enhancement bias. International Information Institute, 19(4), 82-86.

Yukl, G., N. and Falbe, C. M. (1990). Influence tactics and objectives in upward, downward, and lateral influence attempts. Journal of Applied Psychology, 75, 132-140.

Yukl, G., and Michel, J. (2006). Proactive influence tactics and leader-member exchange. In C. A. Schriesheim \& L. Neider (Eds.), Power and influence in organizations: Research in management (pp. 87-103). Greenwich, CT: Information Age Publishing

Yukl, G., Seifert, C. F., and Chavez, C. (2008). Validation of the extended influence behavior questionnaire. The Leadership Quarterly, 609-621. 


\section{Kaynakça Bilgisi / Citation Information}

Özkan, H. and Avan, Y. (2021). Determining the relationship between influence tactics used by school principals and leader- member exchange. OPUS-International Journal of Society Researches, 17(38), 4903-4927. DOI: 10.26466/opus.764564. 